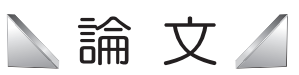

Original Paper

\section{微量のアンチモンを含む電解採取浴からの亜鉛の 電析挙動と結晶組織に及ぼすゼラチンの影響 *}

\title{
Effect of Gelatin on the Deposition Behavior and Crystal Texture of Zinc from Electrowinning Solution Containing Extremely Low Concentration of Antimony
}

\author{
by Hiromitsu YAMASHITA ${ }^{\mathrm{a}}$, Satoshi OUE ${ }^{\mathrm{b}}$, Nobuyoshi $\mathrm{SOGABE}^{\mathrm{c}}$ and Hiroaki NAKANO ${ }^{\mathrm{d}}$
}

a. Postgraduate Student, Graduate School of Engineering, Kyushu University, 744, Motooka, Nishi-ku, Fukuoka 819-0395, now HINODE, Ltd.

b. Assistant Professor, Faculty of Engineering, Kyushu University

c. Assistant Manager, New Product \& Process Development Center, Technology Management Division, Metals, Minerals \& Environmental Engineering Sector, MITSUI KINZOKU \& SMELTING CO.,Ltd., 1-5-1 Shio-machi Takehara-shi Hiroshima 725-0025

d. Professor, Faculty of Engineering, Kyushu University

(Corresponding author, E-mail: nakano@zaiko.kyushu-u.ac.jp)

\begin{abstract}
The effect of gelatin on the deposition behavior and the crystal texture of $\mathrm{Zn}$ from the electrowinning solution containing an extremely low concentration of antimony was investigated. In a solution containing $10 \mu \mathrm{g} / \mathrm{L}$ of antimony only, the both polarization curves for $\mathrm{Zn}$ deposition and hydrogen evolution were depolarized by 10 to 20 $\mathrm{mV}$. The current efficiency for $\mathrm{Zn}$ deposition was slightly higher in solution containing $10 \mu \mathrm{g} / \mathrm{L}$ of antimony and 1 $\mathrm{mg} / \mathrm{L}$ of gelatin than that in solution without antimony and gelatin. Although the large holes resulting from the foam mark of hydrogen evolution were observed in $\mathrm{Zn}$ deposited from a solution containing $10 \mu \mathrm{g} / \mathrm{L}$ of antimony, the gelatin extinguished the large holes. The crystallite size of $\mathrm{Zn}$ was decreased with increasing antimony concentration in solutions with and without gelatin. In a solution containing $10 \mu \mathrm{g} / \mathrm{L}$ of antimony and $1 \mathrm{mg} / \mathrm{L}$ of gelatin, the deposited $\mathrm{Zn}$ showed an unoriented dispersed type of crystals, which was more uniform and finer than that in the solutions containing gelatin and antimony alone. In a solution containing $10 \mu \mathrm{g} / \mathrm{L}$ of antimony and $10 \mathrm{mg} / \mathrm{L}$ of gelatin, the deposited $\mathrm{Zn}$ was composed of mixture of fine fibrous and granular crystals. Although $\mathrm{Zn}$ platelet crystals grew largely perpendicular to substrate in a solution containing $10 \mathrm{mg} / \mathrm{L}$ of gelatin only, the coexistent antimony suppressed the coarsening and the preferred orientation of $\langle 11 \overline{2} 0>$ and $<10 \overline{1} 0>$ of $\mathrm{Zn}$ crystals. Even in a solution containing extremely low concentration of antimony as $10 \mu \mathrm{g} / \mathrm{L}$, the crystal texture of $\mathrm{Zn}$ deposited from the solution in the coexistence of gelatin was obviously different from those in the solutions containing gelatin and antimony alone, showing the synergistic effect of gelatin and antimony on the crystal texture of $\mathrm{Zn}$.
\end{abstract}

KEY WORDS: Zinc, Electrowinning, Gelatin, Antimony, Current Efficiency, Polarization Curve, Crystal Orientation

\section{1. 緒言}

高硫酸濃度溶液からの Zn 電析は，臨界電流密度以上の電流密 度において小さな電析過電圧にて高い電流効率で進行する。とこ ろが液中一不純物が混入して, 臨界電流密度が上昇すると, Zn 電析の電流効率は著しく低下寸る ${ }^{1-6)}$ 。不純物の中でもアンチモ

*2014 年 5 月 28 日受付 2014 年 9 月 9 日受理

1. 九州大学大学院 工学府物質プロセス工学専攻 学生 (現 : 日之出水道機 器株式会社)

2. 正会員 九州大学大学院工学研究院 材料工学部門 助教

3. 三井金属釷業 金属・資源事業本部 技術統括部 金属・資源開発センター 主査

4. 正会員 九州大学大学院 工学研究院 材料工学部門 教授

[ 著者連絡先 ] FAX: 092-802-2990 E-mail: nakano@zaiko.kyushu-u.ac.jp

キーワード : 亜鉛, 電解採取, ゼラチン，アンチモン，電流効率，分極曲 線, 配向性
ンは，電解液中で酸素を含む化合物として存在し水素発生反応の 触媒として作用するため, Zn の臨界電流密度を大きく上昇させ ることが報告されている ${ }^{7-12)}$ 。

一方，陰極表面を平滑にするため， $\mathrm{Zn}$ 電解採取液には，ゼラ チンが添加されている ${ }^{13-15)}$ 。アンチモンと有機系添加剂が共存 すると電流効率が改善されるという報告がある ${ }^{9,10,16-20)}$ が $\mathrm{Zn}$ の電析挙動と結晶組織に及ぼすアンチモンと有機系添加剤の相乗 効果についてはこれまでほとんど報告されていない。そこで著者 らは, 前報にて Zn の電析挙動と結晶組織に及ぼすアンチモンと ゼラチンの相乗効果について検討した ${ }^{21)}$ 。アンチモンが 50,100 $\mu \mathrm{g} / \mathrm{L}$ 存在すると, $200 \mathrm{~A} / \mathrm{m}^{2}$ 以下の低電流密度域で電流効率は大 きく低下寸るがゼラチンが共存するとアンチモンによる電流効率 の低下が大幅に緩和され, また電析 Zn は, ゼラチンおよびアン チモンを単独で添加した場合とは異なる結晶組織を示すことを報 
Table 1 Electrolysis conditions to investigate the partial polarization curve for $\mathrm{Zn}$ deposition.

\begin{tabular}{l|lll}
\hline \multirow{4}{*}{$\begin{array}{l}\text { Bath } \\
\text { composition }\end{array}$} & $\mathrm{Zn}^{2+}$ & $(\mathrm{mol} / \mathrm{L})$ & 0.765 \\
& $\mathrm{H}_{2} \mathrm{SO}_{4}$ & $(\mathrm{~mol} / \mathrm{L})$ & 1.53 \\
& Gelatin & $(\mathrm{mg} / \mathrm{L})$ & 1 \\
& Antimony & $(\mu \mathrm{g} / \mathrm{L})$ & 10 \\
\hline \multirow{5}{*}{ Operating } & Current density & $\left(\mathrm{A} / \mathrm{m}^{2}\right)$ & $100 \sim 2000$ \\
& Temperature & $\left({ }^{\circ} \mathrm{C}\right)$ & 40 \\
& Amount of charge $\left(\mathrm{C} / \mathrm{m}^{2}\right)$ & $2.1 \times 10^{5}$ \\
& Cathode & $\mathrm{Al}\left(1 \times 2 \mathrm{~cm}^{2}\right)$ \\
& Anode & $\mathrm{Pt}\left(1 \times 2 \mathrm{~cm}^{2}\right)$ \\
& Electrolyte volume $(\mathrm{L})$ & 0.5 \\
& Quiescent bath & \\
\hline
\end{tabular}

告した ${ }^{21)}$ 。しかし, アンチモン濃度が更に低い場合のゼラチン との相乗効果については, 不明な点が多い。そこで本研究では, アンチモン濃度が極微量の $10 \mu \mathrm{g} / \mathrm{L}$ を標準条件として, Zn の電 析挙動と結晶組織に及ぼすゼラチンとの相乗効果について調查を 行なった。

\section{2. 実 験 方 法}

Table 1 に Zn 電析の部分分極曲線を測定するための電解液組成 および電解条件を示す。電解液の基本組成は $\mathrm{Zn}^{2+} 0.765 \mathrm{~mol} / \mathrm{L}$ ( 50 $\mathrm{g} / \mathrm{L})$, 遊離 $\mathrm{H}_{2} \mathrm{SO}_{4} 1.53 \mathrm{~mol} / \mathrm{L}(150 \mathrm{~g} / \mathrm{L})$ であり, 高純度 $\mathrm{ZnO}(5 \mathrm{~N}$ 相当) を精密分析用硫酸に溶解して作製した。ゼラチン (Rousselot $\mathrm{ASF}$, 分子量 5000) を $1 \mathrm{mg} / \mathrm{L}$ となるように添加した。アンチモン は電解液への $\mathrm{Sb}_{2} \mathrm{O}_{3}$ の溶解速度が遅いため, 酒石酸アンチモン カリウム・ 3 水和物を純水に溶解させ, $\mathrm{Sb}$ (III) イオン濃度が 10 $\mu \mathrm{g} / \mathrm{L}$ となるように添加した。分極曲線を測定する実験では, 陰 極，陽極には片面をエポキシ系樹脂で絶縁被覆したA 1 板 $(1 \times 2$ $\left.\mathrm{cm}^{2}\right)$ および $\mathrm{Pt}$ 板 $\left(1 \times 2 \mathrm{~cm}^{2}\right)$ をそれぞれ用いた。陰極は, 電解前 にエメリー紙 $(600,1500,2000$ 番) およびバフにて研磨後, 酸洗, 電解脱脂を行なった。液量 $0.5 \mathrm{~L}$, 浴温 $40^{\circ} \mathrm{C}$, 通電量 $2.1 \times 10^{5} \mathrm{C} / \mathrm{m}^{2}$, 無摚拌にて $100 \sim 2000 \mathrm{~A} / \mathrm{m}^{2}$ の範囲で定電流電解を行なった。得 られた電析物は硝酸で溶解し, ICP 発光分光分析法により Zn を 定量し $\mathrm{Zn}$ 電析の電流効率を求めた。 $\mathrm{Zn}, \mathrm{H}_{2}$ の部分電流密度は, 全電流密度にそれぞれの電流効率 $(\%) / 100$ を乗じて算出した。水 素発生の電流効率 $(\%)$ は, 100 から Zn の電流効率を差し引いて 求めた。陰極電位は, 参照電極として $\mathrm{Ag} / \mathrm{AgCl}$ 電極 ( 飽和 $\mathrm{KCl}$, $0.199 \mathrm{~V}$ vs. NHE, $25{ }^{\circ} \mathrm{C}$ ) を用いて測定し, 標準水素電極基準に換 算して表示した。

長時間電析における $\mathrm{Zn}$ の電流効率, 結晶組織を調べるため, 陰極に $\mathrm{A} 1$ 板 $\left(6 \times 8 \mathrm{~cm}^{2}\right)$, 陽極に実操業で使用されている $\mathrm{Pb}-\mathrm{Ag}$ 合金板 $\left(6 \times 8 \mathrm{~cm}^{2}\right)$ を用い, 電流密度 $500 \mathrm{~A} / \mathrm{m}^{2}$, 浴温 $40{ }^{\circ} \mathrm{C}$, 総液 量 3.0L にて溶液を循環させながら陰極の片面に 6 時間の連続電 解を行った。電解槽のサイズは縦 $8.5 \mathrm{~cm} \times$ 横 $13 \mathrm{~cm} \times$ 液深さ $9.5 \mathrm{~cm}$ であり, 液の容量は $1.05 \mathrm{~L}$, 陽極と陰極の極間距離は $3 \mathrm{~cm}$ とした。 Table 2 に連続電解の液組成拉よび電解条件を示寸。 $\mathrm{Zn}^{2+}$ イ才 ンは補給用の中性硫酸亜鉛溶液 $\left(\mathrm{Zn}^{2+} 2.52 \mathrm{~mol} / \mathrm{L}\right)$ を流入量 $0.26 \mathrm{~m}$ $\mathrm{L} / \mathrm{min}$ にて循環槽へ連続補給し, 循環槽から電解槽への流入量 は $150 \mathrm{~m} \mathrm{~L} / \mathrm{min}$ とした。電析 Zn の電流効率は電析前後の陰極 の質量差により算出した。また Znの表面および断面の形態は SEM により観察し, 結晶配向性はX 線回折装置 $(\mathrm{Cu}-\mathrm{K} \alpha$, 管電 圧 $40 \mathrm{kV}$ ，管電流 $20 \mathrm{~mA}$ ）により測定した。結晶配向性は 0002 か ら $11 \overline{2} 2$ 反射の X 線回折強度を測定した後, Willson と Rogers の 方法 ${ }^{22)}$ で求めた配向指数により表示した。電析 $\mathrm{Zn}$ の結晶子の サイズは, X 線の $10 \overline{1} 1$ 反射の半值幅から Scherrerの式 ${ }^{23)}$ を用い て算出した。また, 電析 Zn の表面を共焦点レーザー走査型顕微
Table 2 Long-term electrolysis conditions.

\begin{tabular}{l|lll}
\hline \multirow{3}{*}{$\begin{array}{l}\text { Bath } \\
\text { composition }\end{array}$} & $\mathrm{Zn}^{2+}$ & $(\mathrm{mol} / \mathrm{L})$ & 0.765 \\
& $\mathrm{H}_{2} \mathrm{SO}_{4}$ & $(\mathrm{~mol} / \mathrm{L})$ & 1.53 \\
& Gelatin & $(\mathrm{mg} / \mathrm{L})$ & $1 \sim 10$ \\
& Antimony & $(\mu \mathrm{g} / \mathrm{L})$ & $10 \sim 100$ \\
\hline \multirow{5}{*}{$\begin{array}{l}\text { Operating } \\
\text { conditions }\end{array}$} & Current density & $\left(\mathrm{A} / \mathrm{m}^{2}\right)$ & 500 \\
& Temperature & $\left({ }^{\circ} \mathrm{C}\right)$ & 40 \\
& Cathode & \multicolumn{2}{c}{$\mathrm{Al}\left(6 \times 8 \mathrm{~cm}^{2}\right)$} \\
& Anode & $\mathrm{Pb}-\mathrm{Ag}\left(6 \times 8 \mathrm{~cm}^{2}\right)$ \\
& Electrolysis duration $(\mathrm{h})$ & 6 \\
& Electrolyte volume $(\mathrm{L})$ & 3.0 \\
& \multicolumn{4}{l}{ Circulated electrolyte $(\mathrm{mL} / \mathrm{min})$} & 150 \\
\hline
\end{tabular}

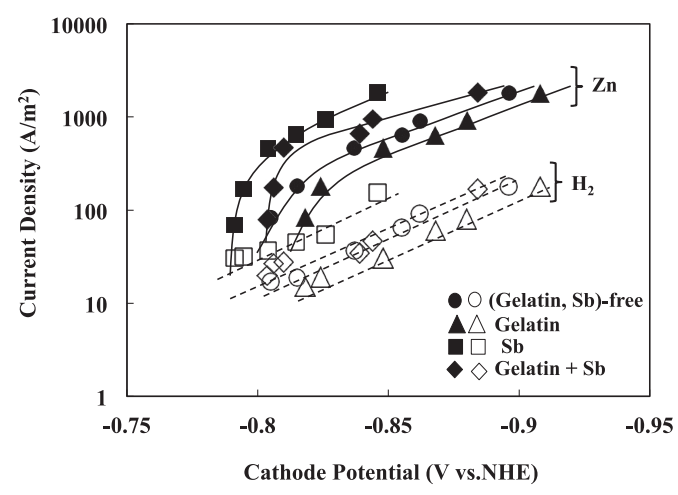

Fig.1 Effect of gelatin and antimony on the partial polarization curves for $\mathrm{Zn}$ deposition and hydrogen evolution. (Gelatin:1 mg/L, Antimony:10 $\mu \mathrm{g} / \mathrm{L}, 2.1 \times 10^{5} \mathrm{C} / \mathrm{m}^{2}$ )

鏡 (KEYENCE, VK-971) により観察した。次に導電性樹脂に包埋 した試料断面をアルミナ粉末 (粒径 $1,0.3,0.1 \mu \mathrm{m}$ ) を用いて鏡面 研磨し, その後 $\mathrm{Ar}$ イオンミリングによりエッチングを行い, 電 子後方散乱回折像 (Electron Back Scatter Diffraction Pattern, EBSD) 法により結晶方位を測定した。EBSD では, 電析 Zn 表面の法線 方向と一致する Reference direction (RD) の結晶方位を電析 Zn 断 面から測定した。

\section{3. 実 験 結 果}

\section{3・1 Zn の電析挙動に及ぼすゼラチン, アンチモンの影響}

Fig. 1 に $\mathrm{Zn}$ 電析, $\mathrm{H}_{2}$ 発生の部分分極曲線に及ぼすゼラチン, アンチモン添加の影響を示す。ゼラチン, アンチモンの添加に かかわらず Zn 電析の部分分極曲線は, Zn の部分電流密度が 200 $\sim 500 \mathrm{~A} / \mathrm{m}^{2}$ の領域で大きく屈曲し, その高電流密度域で分極が 大きくなった。高電流密度域で分極が大きくなったのは, 濃度 過電圧が増加したためである。一方, $\mathrm{H}_{2}$ 発生の部分分極曲線は, 本研究の測定範囲では何れも直線状であった。ゼラチンのみを $1 \mathrm{mg} / \mathrm{L}$ 添加すると $\mathrm{Zn}$ 電析, $\mathrm{H}_{2}$ 発生の部分分極曲線は共に $10 \sim$ $15 \mathrm{mV}$ 程度分極した。 $\mathrm{Zn}$ 電析, $\mathrm{H}_{2}$ 発生の分極の程度はほぼ同等 であった。それに対して, アンチモンのみを $10 \mu \mathrm{g} / \mathrm{L}$ 添加すると $\mathrm{Zn}$ 電析, $\mathrm{H}_{2}$ 発生の部分分極曲線は共に $10 \sim 20 \mathrm{mV}$ 程度復極した。 アンチモンは，陰極にほとんど析出しないが酸素を含む化合物と して存在し水素発生反応の触媒として作用することが報告されて おり ${ }^{7-12)}$, 本研究でも同様の結果が得られた。一方, $\mathrm{Zn}$ 電析も 今回実験を行った全電流密度域でアンチモン添加により復極して おり, Zn 電析に対しても触媒作用のあることが分かった。アン チモンを $50,100 \mu \mathrm{g} / \mathrm{L}$ 添加した場合も同様に $\mathrm{Zn}$ 電析が復極する 傾向があることが報告されている ${ }^{21)}$ 。ゼラチン $1 \mathrm{mg} / \mathrm{L}$ とアンチ モン $10 \mu \mathrm{g} / \mathrm{L}$ が共存した場合は, $\mathrm{Zn}$ 電析, $\mathrm{H}_{2}$ 発生の部分分極曲 線は共にゼラチンとアンチモンが存在しない場合に比べ復極して 


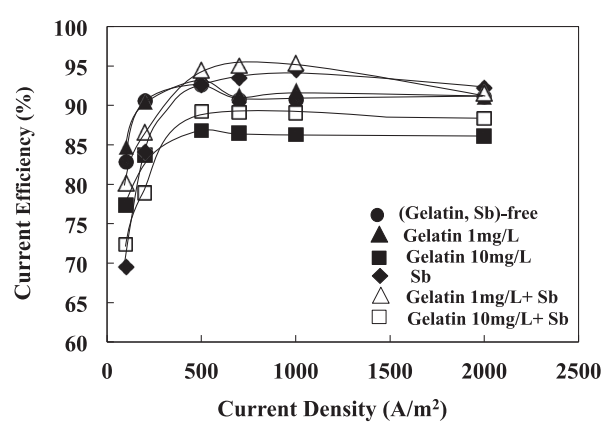

Fig.2 Effect of gelatin and antimony on the current efficiency for $\mathrm{Zn}$ deposition at various current densities. (Antimony: $10 \mu \mathrm{g} / \mathrm{L}$, Amount of charge: $2.1 \times 10^{5} \mathrm{C} / \mathrm{m}^{2}$ )

おり，アンチモンによる復極効果の方が，ゼラチンの分極効果よ り勝っていることを示している。しかし, $\mathrm{Zn}$ 電析, $\mathrm{H}_{2}$ 発生の復 極の程度は共に，アンチモンのみを添加した場合より小さくなっ ており，アンチモンの復極効果をゼラチンが減少させた。

Fig. 2 に各電流密度における Zn 電析の電流効率に及ぼすゼラ チン, アンチモン添加の影響を示す。ゼラチンとアンチモンが存 在しない場合, 電流効率は $500 \mathrm{~A} / \mathrm{m}^{2}$ で最大となり, それ以上の 電流密度では若干低下した。ゼラチンを $1 \mathrm{mg} / \mathrm{L}$ 添加すると, 電 流効率は無添加の場合とほぼ同等か若干増加した。しかし, 添 加量を $10 \mathrm{mg} / \mathrm{L}$ まで増加すると, 全電流密度域で電流効率は 5 〜 $10 \%$ 程度低下した。一方, アンチモンが $10 \mu \mathrm{g} / \mathrm{L}$ 存在すると, $100 \mathrm{~A} / \mathrm{m}^{2}$ の低電流密度で電流効率は低下した。ゼラチンとアン チモンが共存した場合, $100 \mathrm{~A} / \mathrm{m}^{2}$ でのアンチモンによる電流効 率の低下が緩和された。また， $500 〜 1000 \mathrm{~A} / \mathrm{m}^{2}$ では $1 \mathrm{mg} / \mathrm{L}$ のゼ ラチンが共存した場合に電流効率は最大となっており, ゼラチン とアンチモンの相乗効果が見られた。

Fig. 3 に $500 \mathrm{~A} / \mathrm{m}^{2}$ にて 6 時間 Zn 電析の電流効率に及ぼすゼラ チン, アンチモン添加の影響を示す。アンチモンが存在しない 場合, 電流効率はゼラチンを $1 \mathrm{mg} / \mathrm{L}$ 添加すると, 無添加の場合 よりやや増加した。しかし, ゼラチンの添加量が $5,10 \mathrm{mg} / \mathrm{L}$ と 増加すると電流効率は無添加の場合より $5 \%$ 程度低下した。Fig. 1 に示すようにゼラチンを添加すると $\mathrm{Zn}$ 電析, $\mathrm{H}_{2}$ 発生共に抑制 されるが, この電流効率の結果は, ゼラチンを $1 \mathrm{mg} / \mathrm{L}$ 添加する と $\mathrm{Zn}$ 電析より $\mathrm{H}_{2}$ 発生の方がより強く抑制され，ゼラチンを 5 , $10 \mathrm{mg} / \mathrm{L}$ 添加すると $\mathrm{H}_{2}$ 発生より $\mathrm{Zn}$ 電析の方がより強く抑制さ れることを示している。次に, アンチモンが $10 \mu \mathrm{g} / \mathrm{L}$ 存在する場 合, ゼラチンが共存しないと電流効率はアンチモンが存在しない 場合とほぼ同一であるが, ゼラチンを $1 \mathrm{mg} / \mathrm{L}$ 共存させると, ゼ ラチンのみまたはアンチモンのみを添加した場合より, 電流効率 は僅かに増加した。電流効率はゼラチンを $5,10 \mathrm{mg} / \mathrm{L}$ 共存させる と $1 \mathrm{mg} / \mathrm{L}$ 共存させた場合より若干低下した。今回検討した範囲 では, $10 \mu \mathrm{g} / \mathrm{L}$ のアンチモンと $1 \mathrm{mg} / \mathrm{L}$ のゼラチンが共存した場合 に電流効率は最大となった。これは, この濃度においてアンチモ ンによる $\mathrm{Zn}$ 電析の復極効果とゼラチンによる $\mathrm{H}_{2}$ 発生の抑制効 果がバランス良く作用したためと考えられる。最後に, アンチモ ンが $50,100 \mu \mathrm{g} / \mathrm{L}$ 存在する場合, ゼラチンが共存しないと電流効 率は大きく低下したが，ゼラチンが共存すると電流効率の低下は 大幅に緩和された。ゼラチンの濃度が高くなるほど, アンチモン による電流効率の低下は少なくなった。また, ゼラチンの濃度が $5,10 \mathrm{mg} / \mathrm{L}$ の場合, アンチモンが共存した方が, むしろ電流効率 が高くなるケースもあり, ゼラチンとアンチモンの相乗効果が見 られた。

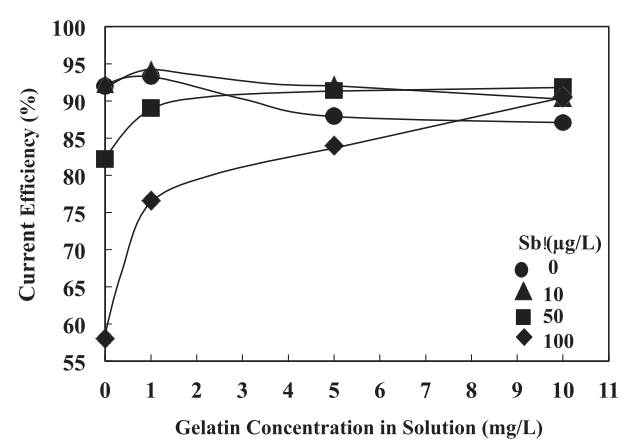

Fig.3 Effect of gelatin and antimony on the current efficiency for $\mathrm{Zn}$ deposition at $500 \mathrm{~A} / \mathrm{m}^{2}$ for 6 hours.

\section{$3 \cdot 2$ 電析 Zn の形態に及ぼすゼラチン, アンチモンの影響}

Fig. 4 に $500 \mathrm{~A} / \mathrm{m}^{2}$ にて 6 時間電析後の $\mathrm{Zn}$ 表面形態に及ぼすゼ ラチン, アンチモン添加の影響を示す。ゼラチンとアンチモンが 存在しない場合 (a), Zn の板状結晶が大きく成長し, 素地に対し て大きく傾斜した形態となった。ゼラチンを $1 \mathrm{mg} / \mathrm{L}$ 添加すると (b)，Znの板状結晶が微細化してそれらの結晶が集合して塊状結 晶を形成した。ゼラチンの添加量を $5 \mathrm{mg} / \mathrm{L}$ と増加させると (c) 塊 状結晶が消出し, エッジが明瞭な板状結晶が形成され, ゼラチン の添加量を $10 \mathrm{mg} / \mathrm{L}$ と更に増加させると (d) Zn の板状結晶が小さ くなり, 積層して素地に対して直立した形態となった。アンチモ ンを $10 \mu \mathrm{g} / \mathrm{L}$ 添加すると (e), $\mathrm{H}_{2}$ ガス発生の気泡痕と思われる大 きな孔が見られたがゼラチンを共存させると $[(\mathrm{f}),(\mathrm{g}),(\mathrm{h})]$, 大き な孔は消失した。アンチモン濃度が $50,100 \mu \mathrm{g} / \mathrm{L}$ の場合, $\mathrm{Zn}$ 電 析の電流効率が低下し $\mathrm{H}_{2}$ ガス発生の気泡痕に由来する大きな孔 が発生することが報告されている ${ }^{21)}$ 。本研究のゼラチン無添加 の条件下ではアンチモン濃度 $10 \mu \mathrm{g} / \mathrm{L}$ では電流効率が変化してい ないことから (Fig. 2), アンチモン存在下では, 水素発生が局所 的に集中して生じることが予想される。ゼラチンが共存すると大 きな孔が消失していることからゼラチンは水素発生を均一にする 効果があると思われる。また，ゼラチンのみを添加した場合，そ の添加量が多くなると Zn の板状結晶が積層して素地に対して直 立した形態となったが (d), アンチモンが共存すると微細な粒状 結晶へと変化した (h) 。

Fig. 4 に示寸電析 Zn の孔以外の箇所を更に倍率を上げて観察 した。その結果を Fig. 5 に示す。ゼラチンとアンチモンが存在し ない場合 (a), Zn の板状結晶は多数の板状結晶の積層からなって おり, 平滑な面は $\mathrm{Zn}$ 六方稠密晶の基底面 [\{0001 $\mathrm{Zn}$ 面 ] と考え られる。ゼラチンを $1 \mathrm{mg} / \mathrm{L}$ 添加すると (b) , 板状結晶は小さく なり, ランダムな方向に積層した。ゼラチンの添加量を $5 \mathrm{mg} / \mathrm{L}$ と増加させると (c) 板状結晶が不明瞭となり, 添加量を $10 \mathrm{mg} / \mathrm{L}$ と更に増加させると (d) 素地に対して直立して積層した $\mathrm{Zn}$ 板状 結晶の先端が直線状に観察された。アンチモンを $10 \mu \mathrm{g} / \mathrm{L}$ 添加す ると (e), Zn の板状結晶が規則的に積層しており, ゼラチンを共 存させると $[(\mathrm{f}),(\mathrm{g}),(\mathrm{h})]$, 板状結晶が小さくなりランダムに積層 して凹凸の小さい表面を形成した。

Fig. 6 に $500 \mathrm{~A} / \mathrm{m}^{2}$ にて 6 時間電析後の $\mathrm{Zn}$ 断面形態に及ぼすゼ ラチン, アンチモン添加の影響を示す。ゼラチンとアンチモン が存在しない場合 (a), 電析 Zn の表層部に三角状の微細な凹凸 が存在した。これは Fig. 4, 5 に示すような素地に対して大きく傾 斜した板状結晶に起因するものと考えられる。ゼラチンを $1 \mathrm{mg} /$ L 添加すると (b), 三角状の微細な凹凸は消失し, 丸みを帯びた 塊状の凹凸が見られた。ゼラチンの添加量を $5 \mathrm{mg} / \mathrm{L}$ と増加させ 


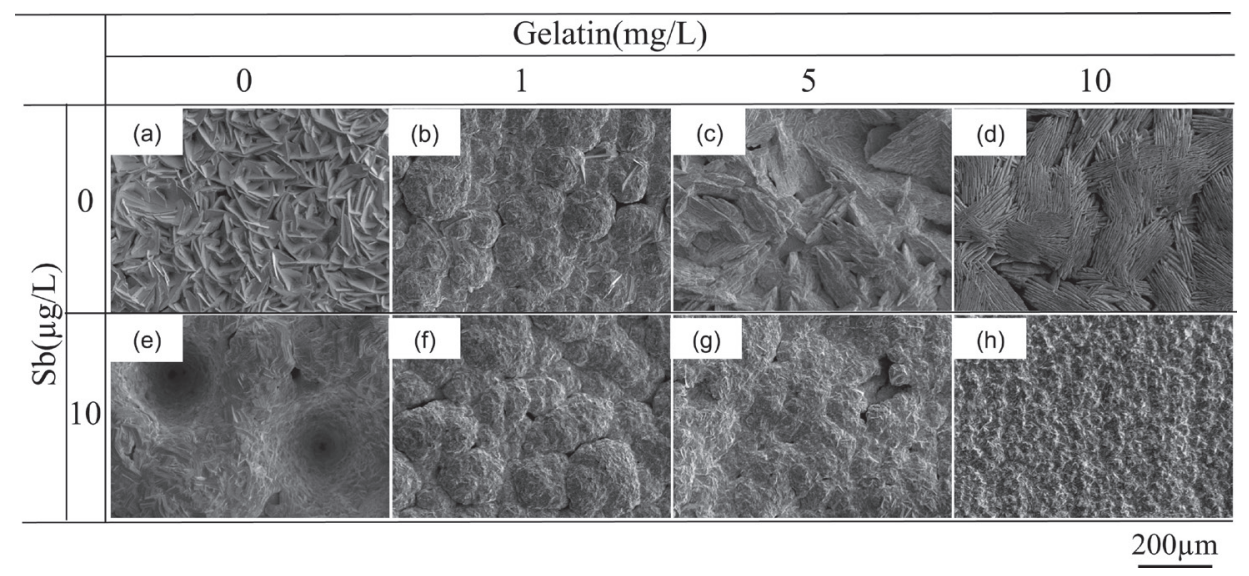

Fig.4 Effect of gelatin and antimony on the surface morphology of $\mathrm{Zn}$ deposited at $500 \mathrm{~A} / \mathrm{m}^{2}$ for 6 hours.

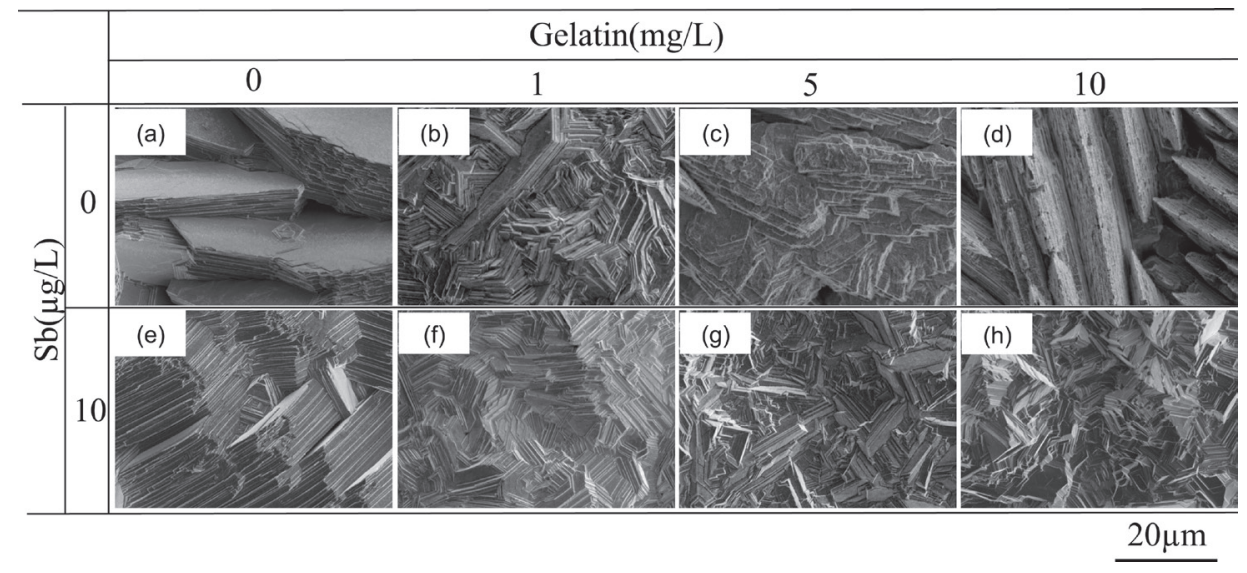

Fig.5 Effect of gelatin and antimony on the surface morphology of $\mathrm{Zn}$ deposited at $500 \mathrm{~A} / \mathrm{m}^{2}$ for 6 hours.

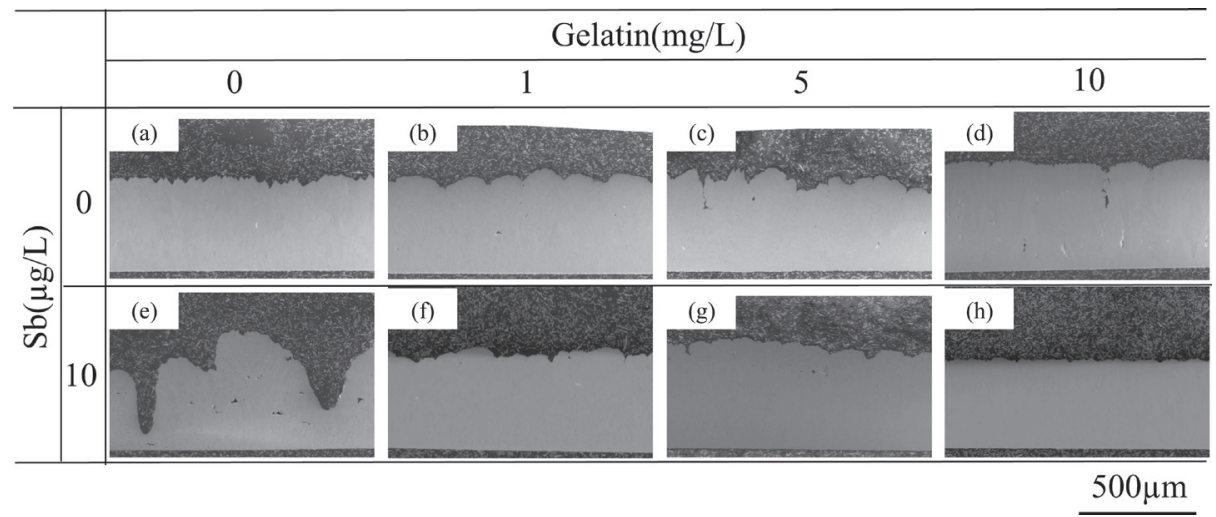

Fig.6 Effect of gelatin and antimony on the cross sectional morphology of Zn deposited at 500A $/ \mathrm{m}^{2}$ for 6 hours.

ると (c) 塊状の凹凸が不規則になり, ゼラチンの添加量を $10 \mathrm{mg} /$ L と更に増加させると (d), 表面は平滑になった。アンチモンを $10 \mu \mathrm{g} / \mathrm{L}$ 添加すると (e)，深い凹部が見られたが，ゼラチンとア ンチモンが共存すると [ (f) , (g) , (h) ], 大きな孔は消失した。また, ゼラチンとアンチモンが共存すると [ (f) , (g), (h) ], ゼラチンの みを添加した場合 [ (b) , (c) , (d) ] より表面が平滑であった。Fig. 5 に示寸電析 Zn の断面の形状は, Fig. 4, 5 に示寸表面形態から予 測されるものと対応していた。

気泡痕に由来する大きな孔の性状を更に調査するため, 電析 Znの表面を共焦点レーザー走査型顕微鏡により観察した。その 結果を Fig. 7 に示す。アンチモンを $10 \mu \mathrm{g} / \mathrm{L}$ 添加すると (a), 直
径 $300 \mu \mathrm{m}$ 前後, 深さ $500 \mu \mathrm{m}$ 前後の円錐状の大きな孔が多数見 られた。ゼラチンを $1,5 \mathrm{mg} / \mathrm{L}$ 共存させると $[(\mathrm{b}),(\mathrm{c})]$, 孔の数お よびその深さが大きく減少した。ゼラチンの濃度を $10 \mathrm{mg} / \mathrm{L}$ と 更に高くすると (d), 孔は消失した。本研究において, 電流効率 100\% でZn が電析すると, Zn の厚さは $513 \mu \mathrm{m}$ となることから, アンチモンを $10 \mu \mathrm{g} / \mathrm{L}$ 添加した場合は, 円錐状の大きな孔は素地 界面近傍に到達していると予想される。

$3 \cdot 3$ 電析 Zn の結晶組織に及ぼすゼラチン, アンチモンの影響

Fig. 8 に $500 \mathrm{~A} / \mathrm{m}^{2}$ にて 6 時間電析後の $\mathrm{Zn}$ の結晶配向性に及ぼ すゼラチン, アンチモン添加の影響を示す。ゼラチンとアンチモ ンが存在しない場合, 電析 Zn の結晶は $\{10 \overline{1} 1\}$ 面への配向がやや 


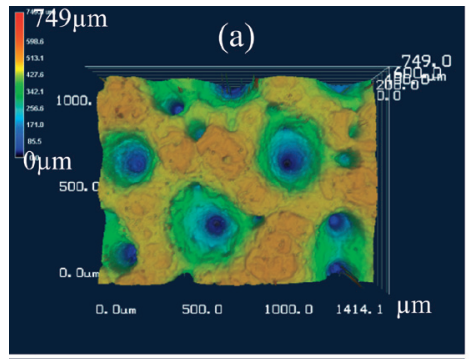

(a) $\mathrm{Sb} 10 \mu \mathrm{g} / \mathrm{L}$

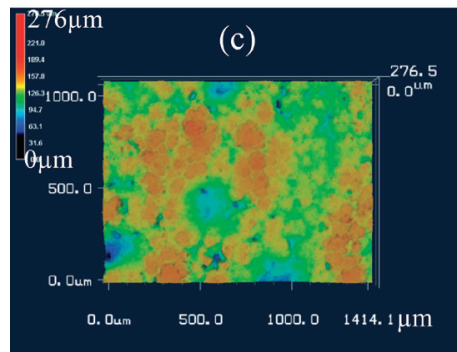

(c) $\mathrm{Sb} 10 \mu \mathrm{g} / \mathrm{L}+$ Gelatin $5 \mathrm{mg} / \mathrm{L}$

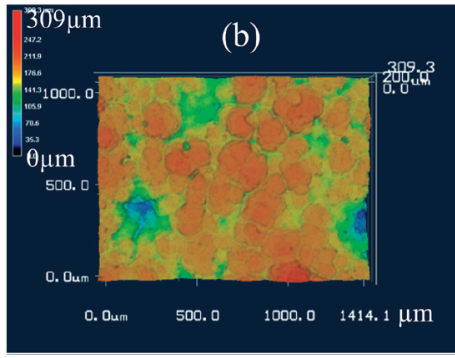

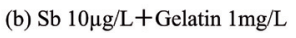

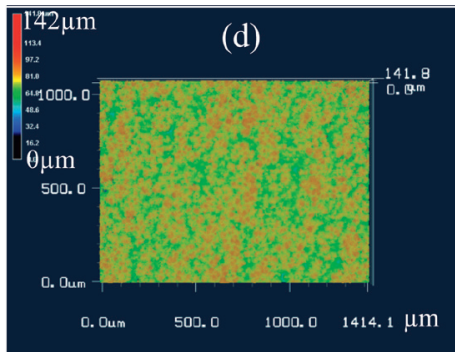

(d) $\mathrm{Sb} 10 \mu \mathrm{g} / \mathrm{L}+$ Gelatin $10 \mathrm{mg} / \mathrm{L}$

Fig.7 Confocal laser scanning microscopy images of surface of $\mathrm{Zn}$ deposited at $500 \mathrm{~A} / \mathrm{m}^{2}$ for 6 hours from solution containing antimony and gelatin.

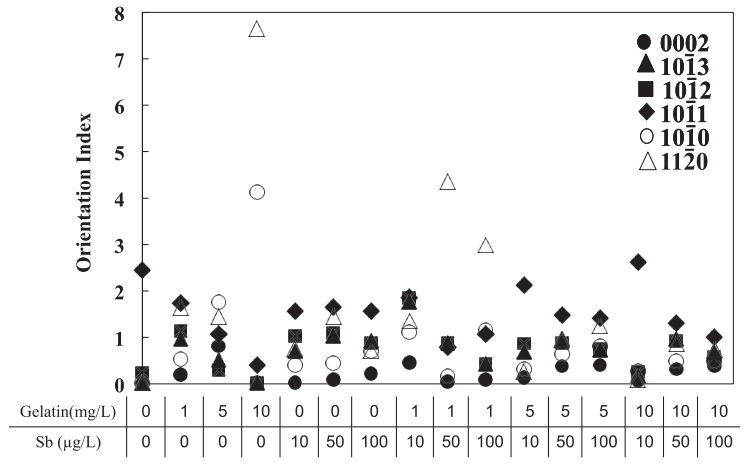

Fig.8 Effect of gelatin and antimony on the crystal orientation of $\mathrm{Zn}$ deposited at $500 \mathrm{~A} / \mathrm{m}^{2}$ for 6 hours.

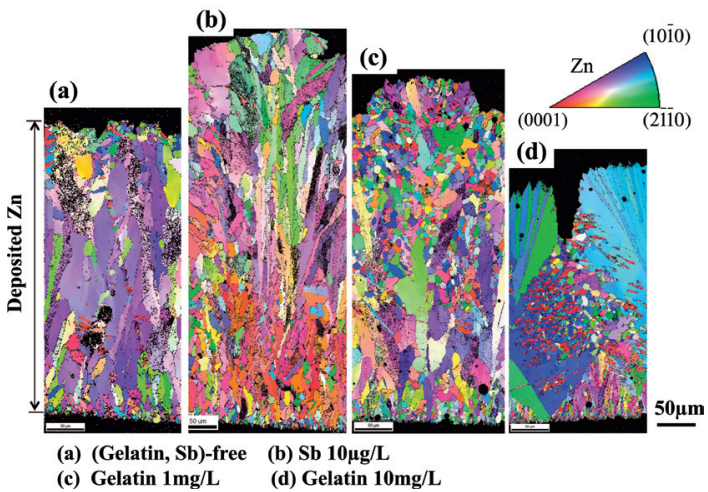

Fig.10 Crystal orientation mapping images of $\mathrm{Zn}$ deposited at $500 \mathrm{~A} / \mathrm{m}^{2}$ for 6 hours in solutions containing antimony or gelatin.

強くなった。ゼラチンのみを添加すると $\{11 \overline{2} 0\},\{10 \overline{1} 0\}$ 面一優 先配向した。特にゼラチン添加量が $10 \mathrm{mg} / \mathrm{L}$ になると, $\{11 \overline{2} 0\}$ へ の優先配向が顕著となった。 $\{11 \overline{2} 0\},\{10 \overline{1} 0\}$ 面への配向は, Zn の板状結晶が素地に対して直立していることを意味している ${ }^{24)}$ 。 実際, Fig. 4, 5 に示すようにゼラチンの添加量が $10 \mathrm{mg} / \mathrm{L}$ になる と, 板状結晶が素地に対して直立した形態となっている。一方,

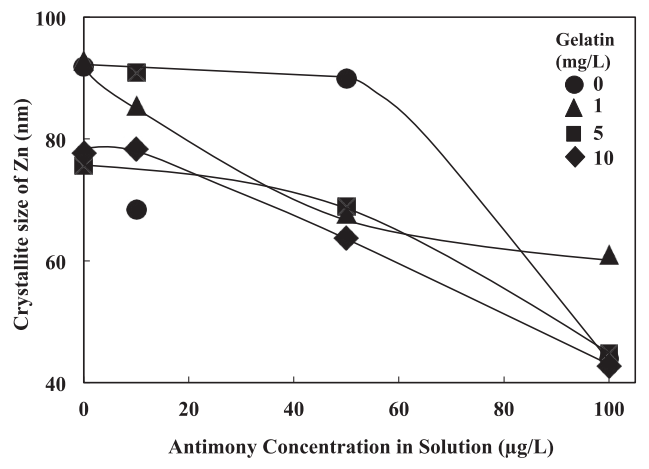

Fig.9 Effect of gelatin and antimony on the average crystallite size of $\mathrm{Zn}$ deposited at $500 \mathrm{~A} / \mathrm{m}^{2}$ for 6 hours.

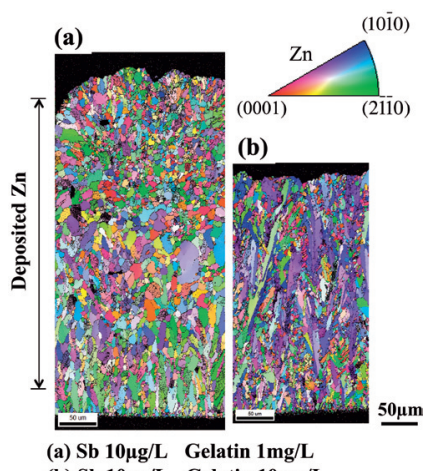

(a) $\mathrm{Sb} 10 \mu \mathrm{g} / \mathrm{L}$ Gelatin $10 \mu \mathrm{mg} / \mathrm{L}$ Gelatin $10 \mathrm{mg} / \mathrm{L}$

Fig.11 Crystal orientation mapping images of $\mathrm{Zn}$ deposited at $500 \mathrm{~A} / \mathrm{m}^{2}$ for 6 hours in solutions containing both gelatin and antimony.

アンチモンのみを添加するといろいろな面に配向しており, 特定 面への優先配向が消失した。ゼラチンとアンチモンが共存した場 合, ゼラチン濃度が $10 \mathrm{mg} / \mathrm{L}$ の場合に着目すると, ゼラチン単独 添加で見られた $\{11 \overline{2} 0\}$ 面への強い配向が無くなっており, アン チモンは，特定面への優先配向を抑制する効果のあることが示唆 された。Pangarovは, 種々の金属についてその 2 次元核形成仕事 
の相対値の計算を行い，与えられた過電圧では，核形成仕事の最 も小さい 2 次元核が形成されるとみなして, 優先配向の過電圧依 存性を示している ${ }^{25,26)}$ 。それによれば，Zn 六方稠密晶の優先 方位は, 過電圧の増加に伴い, $\{0001\} \rightarrow\{10 \overline{1} 1\} \rightarrow\{11 \overline{2} 0\} \rightarrow\{10 \overline{1} 0\}$ 面へと変化する。ゼラチンの添加により $\{11 \overline{2} 0\},\{10 \overline{1} 0\}$ 面への 配向が強くなったのは, Zn の電析過電圧が増加するためと考え られる。一方, アンチモンを添加すると, Fig. 1 に示すように Zn の電析過電圧は減少したが， $\{0001\}$ 面への配向が増加するよう な現象は認められず, 電析の過電圧理論では説明できない結晶配 向性を示した。

Fig. 9 に電析 Zn の結晶子径に及ぼすゼラチン, アンチモン添 加の影響を示す。ゼラチンの有無にかかわらず, 電析 $\mathrm{Zn}$ の結晶 子径は, 総じてアンチモン濃度が高くなる程小さくなった。た だし, アンチモンの濃度 $10 \mu \mathrm{g} / \mathrm{L}$ において, ゼラチン濃度が 0,5 $\mathrm{mg} / \mathrm{L}$ の時データにバラツキが見られた。また, ゼラチンのみを 添加した場合は, ゼラチン濃度が $5,10 \mathrm{mg} / \mathrm{L}$ になると無添加の場 合に比べ, Zn の結晶子径は減少した。電析 Zn の板状結晶のサイ ズは電析過電圧 (平衡電位と電析電位の差) が高くなるほど微細 となる ${ }^{27,28)}$ 。過電圧が高くなると電析物の核形成速度がその成 長速度より相対的に速くなるためである ${ }^{29)}$ 。ゼラチンの添加に より結晶子径が減少したのは, 電析過電圧が増加したためと考 えられる。しかし, アンチモンを添加すると, Zn の電析過電圧 が減少するにもかかわらず, Znの結晶子径は小さくなっており, 電析の過電圧理論では説明できない。この結果は, 酸素を含む化 合物として陰極に吸着するアンチモンが電析 Zn の核形成を促進 寸ることを示唆している。ところで,ここで測定した結晶子径は, $40 \sim 100 \mathrm{~nm}$ 程度であるのに対して, Zn 板状結晶のサイズは Fig. 5 に示すように数十 $\mu \mathrm{m}$ であり, 両者は明らかに一致しない。Zn の六角板状結晶は多数の数十 $\mathrm{nm}$ の粒状結晶から形成されている ことが報告されており ${ }^{30)}$, 本研究の $\mathrm{X}$ 線回折ピークの半值幅か ら測定した結晶子径は, この板状結晶を形成している粒状結晶の サイズに相当するためと考えられる。Zn 結晶粒子径と $\mathrm{Zn}$ 板状結 晶のサイズには相関があり, 結晶粒子径が小さくなると, 板状結 晶のサイズも小さくなる ${ }^{31)}$ 。

Fig. 10 にゼラチンとアンチモンを単独で添加した溶液から得 られた Znの EBSD による結晶方位解析像を示す。以下 Fig. 10, 11 に示寸結晶方位解析像は, 電析 Zn 表面の法線方向と一致する Reference direction (RD) に変換したものである。アンチモンを 10 $\mu \mathrm{g} / \mathrm{L}$ 添加すると (b), 電析初期は無配向分散状の微細な結晶粒と なったが, 途中から繊維状の結晶が多くなった。䋊維状結晶の幅 は, アンチモン無添加の場合に比べ小さくなった。結晶方位に着 目すると, 電析の前半では $<0001>$ に近い配向が目立つが, 後半 では色々な面に配向していた。電析前半に $<0001>$ に近い配向が 多かったのは, アンチモンの添加により電析過電圧が低下したた めと考えられる。しかし, 電析後半では $<0001>$ に近い配向が減 少しており, Zn は電析が進行するとその板状結晶が素地に対し て傾斜していくことを示している。ゼラチンを $1 \mathrm{mg} / \mathrm{L}$ 添加する と (c), 電析前半部には結晶粒の大きい箇所も見られたが, 後半 部では無配向分散状の微細な結晶粒となった。ゼラチンの添加量 を $10 \mathrm{mg} / \mathrm{L}$ に増加させると (d), 電析途中から $<11 \overline{2} 0>,<10 \overline{1} 0>$ 配向の傾斜した䋊維状となり, 表面に達寸るまで大きく成長した。 ところで, Fig. 8 に示寸 XRD による結晶配向性の結果は, 電析 物の表層 $30 \mu \mathrm{m}$ 程度のものであるが, ゼラチン添加量が $10 \mathrm{mg} / \mathrm{L}$ では，先に述べたように $\{11 \overline{2} 0\} ，\{10 \overline{1} 0\}$ 面一優先配向しており， EBSD による結晶方位解析像と一致している。

Fig. 11 にゼラチンとアンチモンが共存した溶液から得られた
Zn の EBSD による結晶方位解析像を示す。 $10 \mu \mathrm{g} / \mathrm{L}$ のアンチモン と $1 \mathrm{mg} / \mathrm{L}$ のゼラチンが共存した場合 (a), 無配向分散状の微細 な結晶粒となった。ゼラチンとアンチモンを単独で添加した場 合 (Fig. 10) より, 均一で微細な結晶となった。10 $\mu \mathrm{g} / \mathrm{L}$ のアンチ モンと $10 \mathrm{mg} / \mathrm{L}$ のゼラチンが共存した場合 (b), 微細な繊維状の 結晶と粒状の結晶が混合した組織となった。結晶方位をみると, $<10 \overline{1} 1>$ に優先配向していた。ゼラチンのみを $10 \mathrm{mg} / \mathrm{L}$ 添加する と, Zn の板状結晶が素地に対して直立して大きく成長したが (Fig. 10），アンチモンが共存すると， Zn 結晶の粗大化および $<11 \overline{2} 0>$, $<10 \overline{1} 0>$ 一の優先配向が抑制された。このようにアンチモンの濃 度が $10 \mu \mathrm{g} / \mathrm{L}$ と極微量の場合においてもゼラチンが共存した溶液 から得られた Zn は, ゼラチンおよびアンチモンを単独で添加し た場合 (Fig. 10) とは異なる結晶組織を示しており, ゼラチンとア ンチモンの相乗効果が認められた。ゼラチン, アンチモンともに 電析 Zn の結晶粒を微細にする効果が見られた。ゼラチンは電析 の過電圧を増加させており, 結晶粒の微細化は過電圧理論で説明 できる。しかし, アンチモンは Zn 電析の過電圧を減少させるに も係わらず結晶粒を微細にしており, 陰極に吸着した酸化アンチ モンが核形成を促進させている可能性がある。すなわち, ゼラチ ンによる核成長の抑制効果とアンチモンによる核形成の促進効果 が相まって電析 Zn の結晶組織に対するゼラチンとアンチモンの 相乗効果が生じていると考えられる。なお, Fig. 10,11において, 電析物の厚さが供試材毎に大きく異なっているが, これは, 観察 を微小領域で行なっているためであり, Fig. 4, 5 に示寸表面形態 からも予想されるように観察位置によって厚さが大きくばらつい ているためである。

\section{4. 結言}

極微量のアンチモンを含む電解採取浴からの Zn の電析挙動と 結晶組織に及ぼすゼラチンの影響について調査した。アンチモ ンのみを $10 \mu \mathrm{g} / \mathrm{L}$ 添加すると $\mathrm{Zn}$ 電析, $\mathrm{H}_{2}$ 発生の部分分極曲線は 共に $10 \sim 20 \mathrm{mV}$ 程度復極した。アンチモン $10 \mu \mathrm{g} / \mathrm{L}$ とゼラチン $1 \mathrm{mg} / \mathrm{L}$ を共存させると, 無添加の場合より, 電流効率は僅かに 増加した。アンチモンのみが $10 \mu \mathrm{g} / \mathrm{L}$ 含まれると, 電析 $\mathrm{Zn}$ に $\mathrm{H}_{2}$ ガス発生の気泡痕と思われる大きな孔が生じたがゼラチンが共 存すると, 大きな孔は消失した。ゼラチンの有無にかかわらず, 電析 Zn の結晶子径は, アンチモン濃度が高くなる程小さくなっ た。10 $\mu \mathrm{g} / \mathrm{L}$ のアンチモンと $1 \mathrm{mg} / \mathrm{L}$ のゼラチンが共存した場合, ゼラチンとアンチモンを単独で添加した場合より, 均一で微細な 無配向分散状の結晶粒となった。ゼラチンとアンチモンを単独 で添加した場合より, 均一で微細な結晶となった。10 $\mu \mathrm{g} / \mathrm{L}$ のア ンチモンと $10 \mathrm{mg} / \mathrm{L}$ のゼラチンが共存した場合, 微細な繊維状の 結晶と粒状の結晶が混合した組織となった。ゼラチンのみを 10 $\mathrm{mg} / \mathrm{L}$ 添加すると, Zn の板状結晶が素地に対して直立して大きく 成長したが，アンチモンが共存すると, Zn 結晶の粗大化および $<11 \overline{2} 0>, \quad<10 \overline{1} 0>$ 一の優先配向が抑制された。このようにアンチ モンの濃度が $10 \mu \mathrm{g} / \mathrm{L}$ と極微量の場合においてもゼラチンが共存 した溶液から得られた Zn は, ゼラチンおよびアンチモンを単独 で添加した場合とは異なる結晶組織を示しており, ゼラチンとア ンチモンの相乗効果が認められた。

\section{References}

1) U.C. Tainton: Trans. Am. Electrochem. Soc., 41 (1922), 389-410

2) S. Ohyama and S. Morioka: Proc. Int. Symp. Extractive Metallurgy of Zn, (Tokyo, 1985), pp.219-234.

3) S. Morioka: Journal of MMIJ, 85 (1969), 631-633.

4) Y. Ogawa: Journal of MMIJ, 49 (1933), 571-579. 
5) T. Ohgai, T. Akiyama and H. Fukushima : Proc. Int. Symp. on the Extraction and Applications of Zinc \& Lead, (Sendai, 1995), p.352-359

6) D. R. Fosnacht and T.J. O'keefe : J. Appl. Electrochem. ,10(1980), 495-504.

7) S. Ohyama: Doctoral dissertation in Tohoku University, (1974), p.13, p.21.

8) D. R. Fosnacht and T. J. O'keefe: Metall. Trans., 14B (1983), 645-655.

9) D. J. Mackinnon: Hydrometallurgy, 35 (1994), 11-26.

10) A. R. Ault and E. J. Frazer: J. Appl. Electrochem., 18 (1988), 583-589.

11) H. Fukushima, T. Akiyama and T. Ohgai: Journal of MMIJ, 110 (1994), 967-972.

12) H. Nakano, S. Oue, T. Noguchi, T. Akiyama and H. Fukushima: Journal of MMIJ, 120 (2004), $39-42$.

13) C.L. Mantell: Electrochemical Engineering, (McGraw-Hill Book Company, Inc., New York, NY, U.S.A., 1960), pp.142-167, 185-192, 210-224.

14) 非鉄金属製錬, ( 日本金属学会, 仙台, 1980), pp.228, 241

15) 電気化学便覧, (電気化学会, 丸善, 東京, 1985), pp.308-327.

16) D. J. Robinson and T. J. O'keefe: J. Appl. Electrochem., 6 (1976), 1-7.

17) A. M. Lafront, W. Zhang, E. Ghali and G. Houlachi: Canadian Metallurgical Quarterly, 48 (2009), 337-346.
18) C. Cachet and R. Wiart: J. Appl. Electrochem., 20 (1990), 1009-1014.

19) B. C. Tripathy, S. C. Das and V. N. Misra: Hydrometallurgy, 69 (2003), 81-88.

20) B. C. Tripathy, S. C. Das, G. T. Hefter and P. Singh: J. Appl. Electrochem., 27 (1997), 673678.

21) H. Yamashita, S. Oue, H. Nakano and N. Sogabe: Journal of MMIJ, 130 (2014), 125-131.

22) K. S. Willson and J. A. Rogers: Tech. Proc. Amer. Electroplaters Soc., 51 (1964), 92-95.

23) T. Watanabe: J. Finish. Soc. Jpn., 40 (1989), 280-286.

24) H. Nakano, K. Araga, M. Iwai and J. Kawafuku: Tetsu-to-Hagane, 84 (1998), 339-344.

25) N. A. Pangarov : J. Electroanal. Chem., $9(1965), 70-85$.

26) N. A. Pangarov: Electrochim. Acta., 9 (1964), 721-726.

27) H. Nakano, H. Fukushima, T. Akiyama and R. Kammel: Metall, 58 (2004), 722-728.

28) H. Nakano and H. Fukushima: Tetsu-to-Hagane, 88 (2002), 236-242.

29) 春山志郎 : 薄膜材料の基礎と応用, (日本金属学会, 仙台, 1987), p.37.

30) K. Kondo, T. Murakami, F. Cerwinski and K. Shinohara : ISIJ Int., 37 (1997), 140-145.

31) H. Nakano, S. Oue, T. Miki, S. Kobayashi and H. Fukushima: Tetsu-to-Hagane, 92 (2006), 501-506. 